\title{
Macro-Microscopic Identification of Dried Flowers of Hibiscus rosa-sinensis $L$. and its Differentiation from Adulterant Rhododendron arboreum Sm.
}

\author{
Nartunai Govindarajan ${ }^{1, *}$, Susikumar Sundharamoorthy ${ }^{2}$, Narayanan Kannan ${ }^{3}$, Ilavarasan Raju ${ }^{4}$
}

\section{Nartunai Govindarajan ${ }^{1, *}$, Susikumar Sundharamoorthy ${ }^{2}$ Narayanan Kannan ${ }^{3}$, Ilavarasan Raju ${ }^{4}$}

\author{
'Research Officer, Department of Phar- \\ macognosy, Captain Srinivasa Murthy Re- \\ gional Ayurveda Drug Development Institute, \\ CCRAS, Govt. of India, Chennai - 600 106, \\ Tamil Nadu, INDIA. \\ ${ }^{2}$ Research Scholar, Captain Srinivasa Murthy \\ Regional Ayurveda Drug Development \\ Institute, CCRAS, Govt. of India, \\ Chennai - 600 106, Tamil Nadu, INDIA. \\ ${ }^{3}$ Laboratory Technician, Captain \\ Srinivasa Murthy Regional Ayurveda Drug \\ Development Institute, CCRAS, Govt. of India, \\ Chennai - 600 106, Tamil Nadu, INDIA \\ ${ }^{4}$ Assistant Director, Captain Srinivasa Murthy \\ Regional Ayurveda Drug Development \\ Institute, CCRAS, Govt. of India, \\ Chennai - 600 106, Tamil Nadu, INDIA. \\ Correspondence \\ Dr. Nartunai Govindarajan \\ Department of Pharmacognosy, \\ Captain Srinivasa Murthy Regional \\ Ayurveda Drug Development Institute, \\ CCRAS, Govt. of India, \\ Chennai - 600 106, Tamil Nadu, INDIA. \\ Phone no : +91-9894154514 \\ E-mail: natrunai@yahoo.co.in \\ History \\ - Submission Date: 27-11-2018; \\ - Review completed: 28-01-2019. \\ - Accepted Date: 11-04-2019
}

DOI : 10.5530/pj.2019.11.98

Article Available online http://www.phcogj.com/v11/i3

Copyright

(c) 2019 Pharmacognosy Journal. This is an open-access article distributed under the terms of the Creative Commons Attribution 4.0 International license.

\begin{abstract}
Background: Hibiscus rosa-sinensis Linn. (Fam.Malvaceae) is a small evergreen shrub cultivated in gardens throughout India. The decoction of flowers is used in Indian system of Medicine for bronchial inflammation, urinary astringent and cardio tonic, to promote growth and to prevent graying of hair. The dried flowers of Rhododendron arboreum Sm. (Fam. Ericaceae) are morphologically looking similar to Hibiscus rosa-sinensis and used as adulterant in the market. Hence, the morphological, Micro-morphological and powder microscopical studies on dried flowers of Hibiscus rosa-sinensis and Rhododendron arboreum was carried out and reported. Objective: To identify the dried flowers of Hisbiscus rosa-sinensis macro-microscopically and to differentiate it from adulterant Rhododendron arboreum. Methods: The morphology and powder microscopy were observed following standard methods and photographed. Results: The colour, taste, arrangement and appearance of calyx, corolla and stamen, trichomes, calcium oxalate crystals, sclereids, oil globules and pollen grains are found to be differentiating diagnostic characters in raw drug/powdered form of dried flowers of Hibiscus rosa-sinensis and Rhododendron arboreum. Conclusion: The finding of present study is helpful in standardization of formulation consists of Hibiscus rosa-sinensis as ingredient in their powdered form and also for authentication/identification of dried flowers of Hibiscus rosa-sinensis.
\end{abstract}

Key words: Hibiscus rosa-sinensis, Macro-microscopy, Adulteration, Rhododendron arboreum, Semparathai, Semparathai.

\section{INTRODUCTION}

Hibiscus rosa-sinensis Linn. (Fam.Malvaceae) is a small evergreen shrub cultivated in gardens throughout India. ${ }^{1,2}$ The flowers are astringent and used as demulcent, emollient, refrigerant, aphrodisiac and emmenagogue. ${ }^{2}$ Decoction of flowers is given for bronchial inflammation, urinary astringent and cardio tonic. ${ }^{2,3}$ The flowers are also used to promote growth and to prevent graying of hair. ${ }^{3}$ The flowers are reported to possess anti-fertility property and useful to correct menstrual disorders. ${ }^{4}$ Even though different colours of flowers are found in varieties, the red flowered variety is preferred in medicine. ${ }^{5}$ The Hibiscus flowers contain anthocyanin pigment, cyanidin diglucoside, flavonoids and vitamins, thiamine, riboflavin, niacin and ascorbic acid. ${ }^{2}$ The alcoholic extract of Hibiscus flowers reported to possess many potentially active antioxidants and anticancer constituents such as quercetin glycosides, riboflavin, niacin, carotene, malvalic acid, gentisic acid, margaric acid and lauric acid. ${ }^{5}$

The dried flowers of Rhododendron arboreum Sm. (Fam.Ericaceae) is morphologically looking similar to Hibiscus rosa-sinensis and used as adulterant in the market. Botanically both plants belong to different genus and family and having diverse medicinal properties. Adulteration of Hibiscus rosa-sinensis may also due to phonetic similarity of names in Tamil, Semparuthi and Semparathai denotes flowers of Rhododendron arboreum and Hibiscus rosa-sinensis respectively. It was noticed that the raw drug being sold as 'Semparuthi and Semparathai' in the market was actually the flowers of Rhododendron arboreum. The finding of present study is helpful in standardization of formulation consists of Hibiscus rosa-sinensis as ingredient in their powdered form and also for authentication/identification of dried flowers of Hibiscus rosa-sinensis.

\section{MATERIALS AND METHODS}

The dried flowers of Hibiscus rosa-sinensis collected from the CSMRADDI campus and market sample (Rhododendron arboreum) sold under the name of Semparathai were purchased from raw drug market. The Voucher specimen of the flowers of Hibiscus rosa-sinensis L. (D/313 F15A) and Rhododendron arboreum (D/313 F15B) were deposited in the
Cite this article: Nartunai G, Susikumar S, Narayanan K, Ilavarasan R. Macro-Microscopic Identification of Dried Flowers of Hibiscus rosa-sinensis L. and its Differentiation from Adulterant Rhododendron arboreum Sm. Pharmacog J. 2019;11(3):613-6. 
department of Pharmacognosy, CSMRADDI, Arumbakkam, Chennai, India for future reference. The morphological, Micro-morphological and powder microscopical studies were carried out by standard methods. ${ }^{6-8}$

\section{RESULTS}

Distinguished differentiating diagnostic features of dried flowers of Hibiscus rosa-sinensis and Rhododendron arboreum are given in Table 1 and 2 and Figure 1-3.

\section{DISCUSSION}

Semparathai, Gurhal phool and Semparuthi, Gularh phool are similar phonetic vernacular names of dried flowers of Hibiscus rosa-sinensis and Rhododendron arboreum in Tamil and Sanskrit respectively. ${ }^{9,10}$ It was noticed that the raw drug being sold as 'Hibiscus, Semparuthi and Semparathai' in the market was actually the flowers of Rhododendron

Table 1: Macroscopic Characters of Dried Flowers of Hibiscus rosa-sinensis and Rhododendron arboretum.

\begin{tabular}{|c|c|c|c|}
\hline S. No. & $\begin{array}{l}\text { Macroscopic } \\
\text { character }\end{array}$ & Hibiscus rosa-sinensis & $\begin{array}{l}\text { Rhododendron } \\
\text { arboreum }\end{array}$ \\
\hline & Colour & Purple & Pinkish Red \\
\hline & Taste & $\begin{array}{l}\text { Slightly sweet and } \\
\text { mucilaginous }\end{array}$ & $\begin{array}{c}\text { Sharp and slightly } \\
\text { astringent }\end{array}$ \\
\hline & Calyx & $\begin{array}{c}\text { Persistent, calyx } 5 \text { lobed, } \\
\text { epicalyx } 5\end{array}$ & Brief, calyx 5 lobed \\
\hline & Corolla & Polypetalous & Gamopetelous \\
\hline & $\begin{array}{l}\text { Pista and } \\
\text { Stamen }\end{array}$ & Monadelphous & Polyadelphous \\
\hline
\end{tabular}

Table 2: Powder Microscopic Characters of Dried Flowers of Hibiscus rosasinensis and Rhododendron arboreum.

\begin{tabular}{|c|c|c|c|}
\hline $\begin{array}{l}\text { S. } \\
\text { No. }\end{array}$ & $\begin{array}{l}\text { Diagnostic } \\
\text { powder } \\
\text { character }\end{array}$ & $\begin{array}{l}\text { Hibiscus rosa- } \\
\text { sinensis }\end{array}$ & Rhododendron arboreum \\
\hline & Pollen grains & $\begin{array}{l}\text { Spherical, Spinuous, } \\
\text { yellow in colour }\end{array}$ & $\begin{array}{l}\text { Tetrahedral tetrads, } \\
\text { Yellowish brown }\end{array}$ \\
\hline & \multirow[t]{2}{*}{ Trichomes } & $\begin{array}{l}\text { Covering trichome, } \\
\text { hooked/ Stellate }\end{array}$ & $\begin{array}{l}\text { Covering trichome, } \\
\text { Numerous, long embedded }\end{array}$ \\
\hline & & $\begin{array}{c}\text { Glandular } \\
\text { multicellular } \\
\text { trichomes }\end{array}$ & $\begin{array}{c}\text { with brownish content } \\
\text { Glandular multicellular } \\
\text { trichomes, Oval/Heart in } \\
\text { shape }\end{array}$ \\
\hline & $\begin{array}{l}\text { Stone cells and } \\
\text { Sclereids }\end{array}$ & Absent & $\begin{array}{l}\text { Isolated and in groups, } \\
\text { varying in size and shape }\end{array}$ \\
\hline & $\begin{array}{l}\text { Calcium } \\
\text { oxalate } \\
\text { crystals }\end{array}$ & $\begin{array}{l}\text { Numerous, Cluster } \\
\text { and rosette }\end{array}$ & A few cluster crystals \\
\hline & Oil globules & Absent & Present \\
\hline & Ovules & $\begin{array}{c}\text { Kidney shaped } \\
\text { embedded with } \\
\text { numerous rosette } \\
\text { crystals }\end{array}$ & Ovate in shape \\
\hline & Starch grains & $\begin{array}{l}\text { Numerous, simple } \\
\text { and compound } \\
\text { (Multi-component) }\end{array}$ & A few simple, large in size \\
\hline & Stomata & $\begin{array}{l}\text { A few Anamocytic } \\
\text { stomata }\end{array}$ & Scarcely found \\
\hline
\end{tabular}

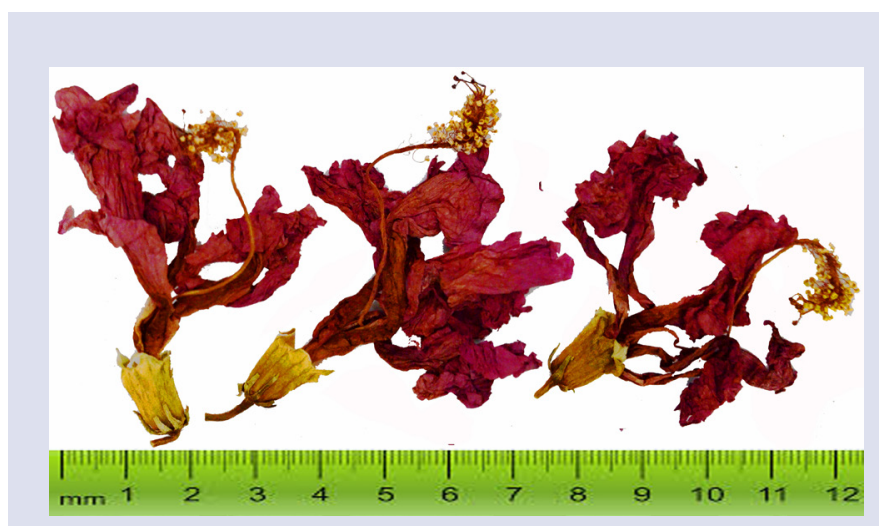

Figure 1: Dried Flowers of Hibiscus rosa-sinensis.

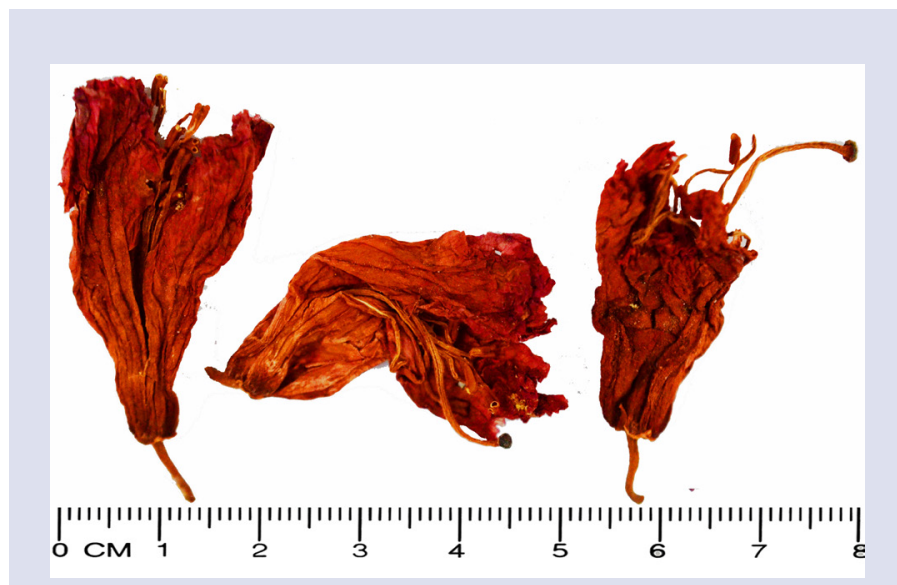

Figure 2: Dried Flowers of Rhododendron arboretum.

arboreum. Thus, the confusion between this two flowers exists in literature and as well as in the market. In this adulteration, scarcity in availability of genuine drug and similar looking plenty available adulterant is the intension.

Pharmacognostic characters of herbal drugs play an important role since particular macro-microcopic features are unique for each plant. The macroscopic and microscopic studies of the herbs should be the first and fundamental step to authenticate the botanical source. Proceeding for chemical methods of standardization, preclinical and clinical evaluation will bear no value if authentic drugs are not used. Macro-microscopic evaluation is simple and cost effective. ${ }^{11,12}$ From the results of this study it is well established that the dried flowers of Hibiscus rosa-sinensis can be easily identified morphologically in the crude drug form and microscopically in the powdered form. The findings of the comparative study on dried flowers of Hibiscus rosa-sinensis and Rhododendron arboreum will be helpful in differentiating their identity. This study sets specific macro-microscopic protocol on dried flowers and powder of Hibiscus rosa-sinensis and also to differentiate it from its adulterant Rhododendron arboreum.

\section{CONCLUSION}

Macro-microscopic studies on dried flowers of Hibiscus rosa-sinensis has been carried out and reported. Findings of this study may be useful for authentication/identification of flowers of Hibiscus rosa-sinensis in 


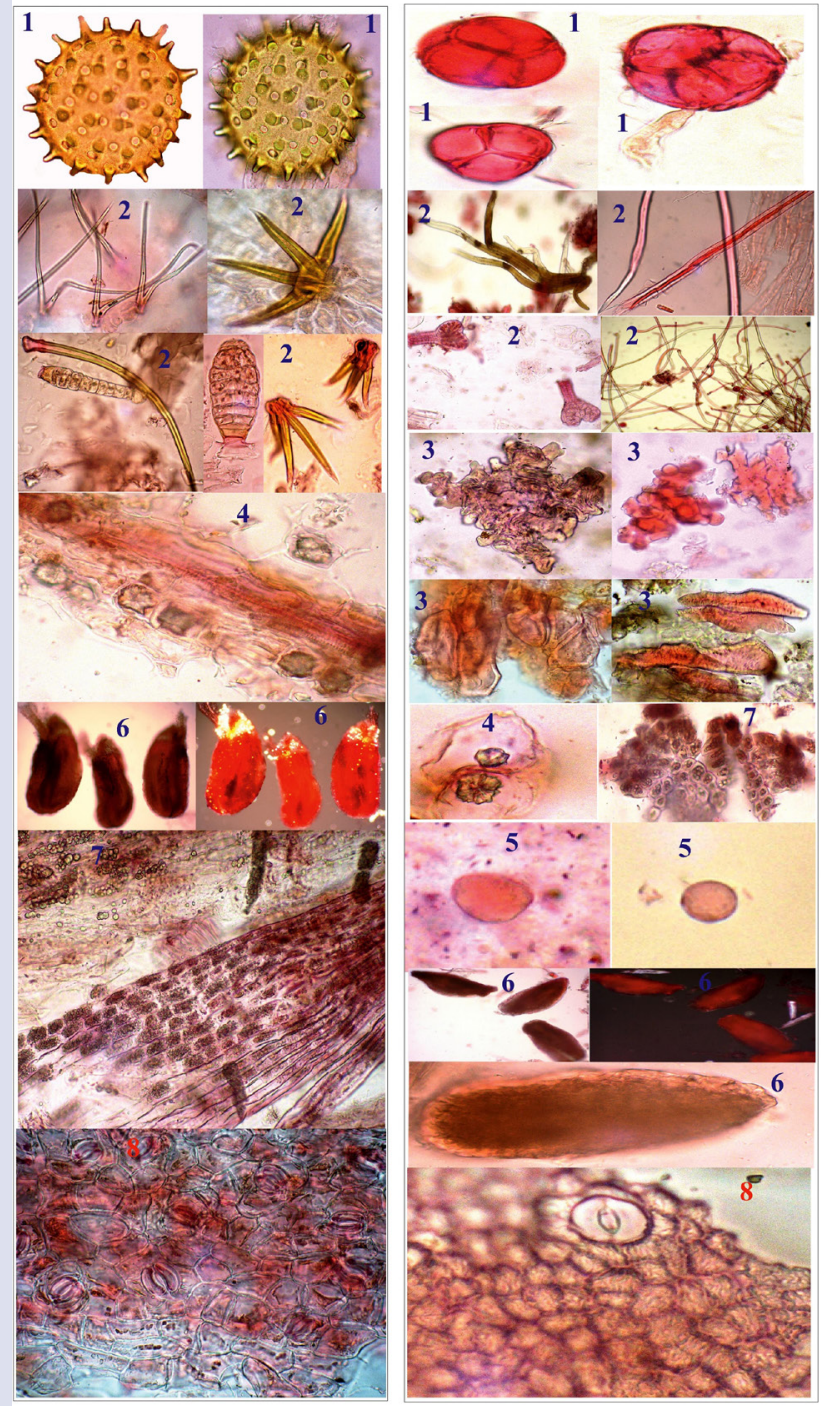

Figure 3: Powder Microscopic Characters of Dried Flowers of Hibiscus rosa-sinensis and Rhododendron arboreum 1, Pollen grains; 2, Trichome; 3, Stone cells and sclereids; 4, Crystals; 5, Oil globules; 6 , Ovule; 7 , Starch grains; 8 , Stomata. crude drug and also in powdered formulation in which it is one of the ingredients.

\section{ACKNOWLEDGEMENT}

The authors are very grateful to the Director General, Central Council for Research in Ayurvedic Sciences, New Delhi, for his encouragement and providing opportunity to conduct this study.

\section{CONFLICT OF INTEREST}

The authors declare no conflict of interest.

\section{ABBREVIATIONS}

Fam: Family; Fig: Figure; CSMRADDI: Captain Srinivasa Murthy Regional Ayurveda Drug Development Institute.

\section{REFERENCES}

1. Gamble JS. Flora of presidency of Madras. Calcutta. 1957;1:68-71.

2. Anonymous, The Wealth of India, Raw materials, H-K. Council of Scientific and Industrial Research, New Delhi. 1959;5:91-2

3. Sharma PC, Yelne MB, Dennis TJ. Database on medicinal Plants used in Ayurveda New Delhi: CCRAS. 2001;4:198

4. Kholkute SD, Mudgal V, Udupa KN. Studies on the anti-fertility potentiality of Hibiscus rosa-sinensis. Planta Medica. 1977;31(1):35-9.

5. Vincenta K, Patel VH. Therapeutic Potential of Hibiscus Rosa Sinensis: A Review. International Journal of Nutrition and Dietetics. 2016;4(2):105-23.

6. Anonymous, The Ayurvedic Pharmacopoeia of India, part-I, First Edition, Government of India, Ministry of Health and Family Welfare, Department of AYUSH, New Delhi. 2008;233-42.

7. Iyengar MA. Pharmacognosy of Powdered Crude Drugs. Manipal Power press: Manipal. 1980.

8. Sass JE. Botanical Microtechnique, Oxford and IBH Publishing co. Calcutta.1958

9. Murugesa MKS, Gunapadam MV. Fourth edition, Publisher; Tamilnadu Siddha Medical Council, Chennai, a text book of Siddha Medicine. 1988;480-2.

10. Ved DK, Goraya GS. Demand and Supply of Medicinal Plants in India. NMPB New Delhi and FRLHT, Bangalore, India. 2007:18.

11. Nartunai G, Arunachalam C, Maheswari B, Cheemalapati VN, Kusuma G, llavarasan R. Pharmacognostical and Phytochemical Evaluation of a Polyherbal Ayurvedic Formulation Trikatu Churna. Journal of Ayurveda Medical Sciences. 2016;1(1):34-40

12. Susikumar S, Nartunai G, Arunachalam C, Ilavarasan R. Macro-Microscopic Atlas on Heartwood of Santalum album L. (Sandalwood). Pharmacognosy Journal. 2018;10(4):731-4

\section{GRAPHICAL ABSTRACT}

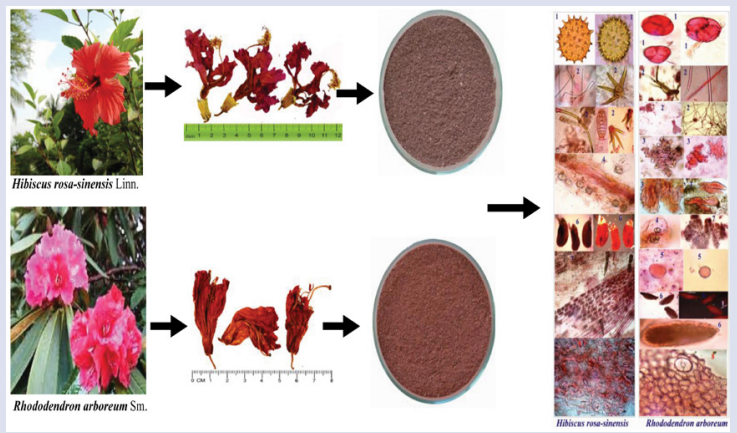

\section{SUMMARY}

- Hibiscus rosa-sinensis Linn. (Fam.Malvaceae) is a small evergreen shrub cultivated in gardens throughout India.

- The decoction of flowers is used in Indian system of Medicine for bronchial inflammation, urinary astringent and cardio tonic, to promote growth and to prevent graying of hair.

- The flowers of Rhododendron arboreum (Fam.Ericaceae) are morphologically looking similar to Hibiscus rosa-sinensis and used as adulterant in the market.

- Hence, the morphological, Micro-morphological and powder microscopical studies on dried flowers of Hibiscus rosa-sinensis and Rhododendron arboreum was carried out and reported.

- Findings of the study helpful in authentication of raw drug and standardization of formulations containing Hibiscus rosa-sinensis Linn. flower as ingredient. 


\section{ABOUT AUTHORS}

Nartunai Govindarajan is a Research Officer (Pharmacognosy) at Captain Srinivasa Murthy Regional Ayurveda Drug Development Institute, Chennai - 600 106, Under CCRAS, Ministry of AYUSH, Govt. of India. His research focused on developing quality standards for medicinal plants used in Ayurveda. He has projects in Intra Mural and Extra Mural Research Schemes. He has experience in the area of Pharmacognosy, developed monographs for Ayurvedic Pharmacopoeia of India and Quality Standards for Indian Medicinal Plants by ICMR.

Susikumar Sundaramoorthy is a Research Scholar at Captain Srinivasa Murthy Regional Ayurveda Drug Development Institute, Chennai - 600 106, Under CCRAS, Ministry of AYUSH, Govt. of India. His doctoral research focused on developing quality standards for medicinal plants used in Ayurveda. He has worked under the ICMR project titled on "Quality Standards for Indian Medicinal Plants and preparation of monograph thereon". He Has experience in the area of Pharmacognosy and Botany.

Cite this article: Nartunai G, Susikumar S, Narayanan K, llavarasan R. Macro-Microscopic Identification of Dried Flowers of Hibiscus rosa-sinensis L. and its Differentiation from Adulterant Rhododendron arboreum Sm. Pharmacog J. 2019;11(3):613-6. 